house with concentrations of sodium chloride ranging from 0.5 to 6.0 milli-equivalents per litre in the applied nutrient solution, have shown that increased chloride in leaves of the same physiological age is associated with increased scopoletin (Fig. 1). Glasshouse-cured tobacco leaves and field-grown cured leaf also show similar relationships in scopoletin and chloride content, and calculations based on the assumption that the spot area is proportional to the logarithm of spot content ${ }^{*}$ give concentrations of scopoletin varying approximately from less than two to one hundred and seventy times greater in the leaf with high-chloride than in one containing a lowchloride concentration.

The increase in scopoletin associated with a higher chloride content in the leaf may account for the typical morphological and anatomical effects produced both in the leaf and generally in the plant: the stunting (also noticeable in virus attack ${ }^{3}$ ) being due to the effect on the indoleacetic acid metabolism, and the thickening of the secondary xylem to increased concentrations of scopoletin at the site of the differentiating tissue. Scopoletin concentrations in the root and stem of tobacco plants under varying chloride treatments are being examined.

As scopoletin passes unchanged into the mainstream smoke on combustion of the tobacco ${ }^{8}$, it may be an important factor in tobacco quality as influenced by sodium chloride in the soil. Other factors which affect the nutrient balance, such as low potash content, also appear to favour the accumulation of scopoletin.

Plant Research Division,

H. D. Fowlen*

Department of Agriculture, Perth,

Western Australia.

* Present address : Department of Biochemistry and Plant Nutrition, The Agricultural Institute, Johnstown Castle, Wexford, Eire.

1 Haas, A. R. C., Soil Sci., 60, 57 (1945).

${ }^{2}$ Wedin, W. F., and Struckmeyer, B. E., Plant Physiol., 33, 137 (1958). ${ }^{3}$ Best, R. J., Austral. J. Exp. Biol, and Med. Sci., 22, 251 (1944).

${ }^{4}$ Tryon, K., Science, 123, 590 (1956).

5 Andreae. W. A., Nature, 170, 83 (1952).

${ }^{6}$ Fisher, R. B., Parsons, D. S., and Morrison, G. A., Nature, 161, 764 (1948).

7 Fowler, H. D., Nature, 168, 1123 (1951)

Yang, C. H., Nagawa, Yasushi, and Wender, S. H., J. Org. Chem., 28, $204(1958)$.

\section{Function of the Osphradium in Bullia (Gastropoda)}

Krijgsman and Brown ${ }^{1}$ have recently described a technique for operating on fully extended and immobilized marine Gastropoda. We have now used this 'water-rigour' method on 124 individuals of Bullia laevissima (Gmelin) preparatory to severing their osphradial nerves in order to discover the function of the osphradium. The osphradium in Gastropoda is generally thought to be an organ of chemo-reception, though the evidence in support of this theory is far from satisfactory. Experiments such as those of Copeland ${ }^{2}$ are not convincing in view of the crude techniques used. A few workers, notably Hulbert and Yonge $^{3}$, have suggested that the osphradium may be concerned with the perception of turbidity; but no experimental data have been presented in support of this view, the only evidence being circumstantial. Detailed histological studies of the osphradium, such as those undertaken by Stork ${ }^{4}$, add little to the argument.
Of the 124 snails on which we operated, 52 did not recover and post-mortem examination revealed damage to the pallium and/or the dorsal pallial artery which passes just below the osphradium. When the remaining 72 snails were killed and dissected after the completion of our experiments, it was found that in some cases the osphradial nerve had not been completely severed, while in others nerves other than the osphradial nerve had been cut or damaged accidentally. The results of experiments on these snails were therefore disregarded. In only 13 cases was the operation completely successful, the osphradial nerve being entirely severed without damage to other structures. Of these 13 snails, 12 lived for more than a week in the laboratory and were offered food on each successive day.

Bullia laevissima normally lies half buried in the sand, under water, only the upper part of the shell and the siphon being visible. It can be caused to emerge actively from the sand if suitable food be placed in or near the water. (A detailed account of this behaviour is given elsewhere by Brown ${ }^{5}$.) However, individuals which have had the osphradial nerve severed fail to emerge, even when presented with their favourite food-the tunicate Pyura. Nevertheless such individuals will feed when placed on the food or touching it, indicating that failure to emerge is not resultant on a disinclination to feed, but rather indicates a deficiency in chemo-perception from a distance. We are therefore of the opinion that chemo-reception is at least the major function of the osphradium in this species.

\section{A. C. BROwN}

R. G. NOBLE

Zoology Department, University of Cape Town, Rondebosch.

Krijgsman, B. J., and Brown, A. C., Nature, 187, 69 (1960).

2 Copeland, M., J. Exp. Zool., 25, 177 (1918).

s Hulbert, G. C. E. B., and Yonge, C. M., Nature, 139, 840 (1937).

S Stork, H. A., Arch. Neerl. Zool., 1, 71 (1934).

${ }^{5}$ Brown, A. C., Z. Morph. Oekol. Tiere (in the press).

\section{CYTOLOGY}

\section{Number of Chromosomes in the Human Cell}

CURRENT work with human chromosomes in many laboratories has resulted in the publication of numerous photographs of chromosomes of human cells both normal and abnormal. Almost all these have been obtained from cells which are selected at least to the extent that they are cells capable of undergoing mitosis one or more times in vitro. These cells are often subjected to physical conditions which might conceivably influence the process of mitosis, that is, temporary chilling, change of $p \mathbf{H}$, etc. Further, in most cases the mitotic process has been disturbed intentionally by the use of colchicine.

Because of the possible significance of these factors, we feel that the accompanying photograph (Fig. 1) will be of interest. It shows an unstained, uncolchicinized bone marrow mitosis obtained within minutes after aspiration from a 59-year-old female. There is clear representation of 46 chromosomes. The correspondence of this and other morphological details with those obtained using colchicine and tissue culture methods is to be noted. We feel this is 